\title{
Dopaminergic Receptor Type 1 Antagonists and its Possible Role as Preventive Treatment of Post-Traumatic Stress Disorder: A Short Review
}

\author{
Thiago C. Moulin
}

Institute of Medical Biochemistry Leopoldo de Meis, Federal University of Rio de Janeiro, Brazil.

\section{ARTICLE INFO \\ Article history: \\ Received on: 16/06/2016 \\ Revised on: 16/08/2016 \\ Accepted on: 09/09/2016 \\ Available online: $28 / 12 / 2016$}

Key words:

PTSD; D1 antagonists;

memory persistence.

\begin{abstract}
Posttraumatic stress disorder (PTSD) is an overreaction to aversive memories and can cause severe health issue. The prevention or treatment memory of PTSD through pharmacological approaches is a rising field, but still with inconclusive results. In this study, the literatures of dopaminergic D1 antagonist were reviewed and author propose that it can be applied to achieve this goal, mainly due to effects on memory persistence. Moreover, administration of D1 antagonists would be simple with few side effects, making this treatment reasonably practical for human use.
\end{abstract}

\section{INTRODUCTION}

Unfortunately, traumatic events are fairly common. Studies report that a range from $40 \%$ to $60 \%$ of the general population have been exposed to some aversive incident during their life (Creamer et al., 2001; Kessler et al., 1995), while some studies enlarge this rate to around $90 \%$ in U.S. (Breslau et al, 1998; Breslau, 2009). These experiences are capable of producing health issues as posttraumatic stress disorder and other forms of psychological impairment. Although exposure rate differs across studies, the lifetime prevalence of PTSD varied within a narrow range: $5-6 \%$ in men and $10-14 \%$ in women (Breslau et al, 1998; Breslau, 2009); and 7\% in a general estimative (Kessler et al., 2007). Despite not well explored in literature, prevention of PTSD through pharmacological treatment is a rising field with some promising studies (Pitman et al, 2005; Fletcher et al., 2010). Investigated drugs, as

* Corresponding Author

Email: moulin@ bioqmed.ufrj.br hydrocortisone (Schelling et al., 2001; Schelling et al., 2004), benzodiazepines (Gelpin et al., 1996; Mellman et al., 1998), escitalopram (Suliman et al., 2015), propranolol (Vaiva et al., 2003; Stein et al., 2007; Pitman et al., 2002), antiepileptics(Stein et al., 2007) and morphine (Bryant et al., 2009; Holbrook et al., 2010) focus primarily on modulating the anxiety-related factors of memory consolidation, diminishing the averseness of threatening experiences.

However, these approaches provide some inconclusive results and no clear evidences of PTSD prevention. A Cochrane review in 2014 concluded that in general, there is and no evidence for the efficacy propranolol, escitalopram, temazepam, and gabapentin (Amos et al., 2014). This lack of effects could be due that not every symptom is associated with fear circuitries (Fletcher et al., 2010; Holbrook et al., 2010). Moreover, there is a limited time of fear memory consolidation (Izquierdo et al., 2016), so this small window of opportunity for administration of prophylactic drugs after a traumatic event increases the necessity for more specific and efficient interventions. 
On other hand, dopamine is a vastly studied neurotransmitter, implicated to have roles in several mental impairments, such as anorexia nervosa (Kontis and Theochari, 2012), depression (Höflich et al., 2012), addiction (Taber et al., 2012) and schizophrenia (Pillai et al., 2012; Seeman, 2010), in which D2 dopaminergic receptor antagonists are broadly used for treatment (Pillai et al., 2012; Miyake et al., 2012).Additionally, several studies correlate mutations in dopamine transporters D2 and D3withsusceptibility to PTSD development (Comings et al., 1996; Lawford et al., 2006; Segman et al., 2002; Wolf et al., 2014). Nevertheless this wide range of influence on brain diseases and the direct impact on PTSD manifestation, no research has up to this date directlytested using dopaminergic modulators to PTSD treatment.

In this review, I suggest that due to the known role of dopamine on memory formation and persistence (Jay, 2003; O'Carroll et al., 2006), dopaminergic receptor antagonists could contribute to prevent PTSD and other psychological impairments related to traumatic incidents.

\section{Dopaminergic control of memory persistence}

Memory traces can be stored for different amounts of time. Biologically significant events tend to generate memories that last longer than every day scenarios, and the capability of storage particular traces through time is called persistence. The hippocampus encodes memory processes and receives neuromodulatory signals from several cortical and subcortical structures. Among these, one of great importance is the ventral tegmental area (VTA), a mesolimbic structure that has dopaminergic projections to hippocampus (Scatton et al., 2005; Swanson, 1982; Kahn and Shohamy, 2013). When the hippocampus detects novel information, a neural signal is thought to pass first via the subiculum to the nucleus accumbens (NAcc), and then, NAcc neurons stimulatethe firing of the VTA. In fact, the dopaminergic loop VTA-hippocampus is assumed to influence processing of information on long-term memory formation and persistence (Jay, 2003; O'Carroll et al., 2006; Lemon et al, 2006; Rossato et al., 2009).

Additionally, the basolateral amygdala (BLA), an area connected to hippocampus and well known for its involvement in fear conditioning, also receives projections from VTA and show D1/D5 receptor expression (Muller et al., 2009). Also, it was shown that a selective dopaminergic D1/D5 receptor antagonist (SCH23390), suppresses long-term potentiation and modulates the acquisition of contextual fear conditioning in bothhippocampus and BLA (Huang et al., 1995; Huang et al., 2007; Heath et al., 2015), indicating that D1-like receptor signaling in these regions are necessary to process fear memory. Thus, this modulatory effect of dopamine on plasticity could give rise to a selective strengthening or weakening of memory traces from hippocampus and amygdala.

Exploring these mechanisms, Bethus et al. demonstrated that intrahippocampal infusions of $\mathrm{SCH} 23390$, modulated the persistence of new memories over time, but not in new paired- associations in an episodic-like memory task, not affecting encoding per se. Furthermore, investigating specific influence in fear memory persistence, Rossato and collaborators showed that intrahippocampal administration of SCH23390 12hrs after an aversive stimulus is capable of induce fear memory persistence depletion by inhibiting the VTA modulatory inputs on hippocampus. In agreement with this, it is shown at synaptic level that hippocampal dopaminergic receptors D1 are necessary for persistence of memory traces, since its activation lowers the threshold for the induction of both synaptic long term potentiation and long term depression (Huang et al., 1995; Frey and Schroeder, 1990).

Several other factors mediate the memory persistence mechanism, as brain derived neurotrophic factor (BDNF) expression and protein synthesis (Bekinschtein et al., 2007), and alterations in their influence reach similar results. However, differently from dopamine modulators, the drugs used to manipulate these factors are usually not efficient or too harmful to human administration.

\section{Treatment, receptor specificity and optimal administration approach}

Supported by the evidences shown so far, our proposal is that dopamine receptor antagonists have the capability of impairing persistence of long term memory and therefore can be applied to prevent aversive memory that could lead to psychological impairments like PTSD. But which are the best pharmacological solutions for this goal?

The most highlighted target is the D1 receptor, because as said, several studies clearly indicate its influence on memory persistence (Jay, 2003; O'Carroll et al., 2006; Lemon et al, 2006; Rossato et al., 2009). Some selective antagonists for this receptor exists, among them the drug SCH-39166 (or ecopipam) that was several times tested for human use in disorders such as drug abuse and compulsive eating, although never approved for medical prescription (Chipkin et al., 1988; Zhang et al., 2009). This scenario is mainly because of side effects such as depression and anxiety, even though these symptoms appear just after chronic intake (Astrup et al., 2007).

Moreover, a main point in the proposed PTSD preventive treatment is the administration time. Since the objective is to control the maintenance and persistence of memory, medicaments should be given preferentially hours, not days, after the traumatic event, in order to impair the necessary VTA modulation and consequent BDNF expression in hippocampus (Bethus et al., 2010; Bekinschtein et al., 2007). To act on this time window, just an acute single dose of the antagonist would be necessary, avoiding these unwanted psychiatric adverse effects.

Another advantage of this proposal is the fact that it does not alter the encoding or retrieval of the memory trace, but the mechanisms that determine its relevance and persistence (Bethus et al., 2010; Rossato et al., 2009). It is an important point, because however memory-modulatory approaches are being considered 
promising, these drugs can raise relevant ethical issues, such the possibility of invalidating testimonials of an event (Parsons and Ressler, 2013; Kolber, 2011).

\section{CONCLUSION}

Presented here is a new alternative to preventing traumarelated mental impairments by acute administration of dopamine D1 antagonists in a specific time-window, known to impair aversive memory persistence. This hypothetical treatment can offer several advantages over the current ones, granted that there is a lack of undesired effects, simplicity in application and unquestionable action over fear persistence. However, the limitation of this treatment is the administration time-window, since optimal administrations should be within a few hours after the traumatic event, requiring to the emergency handling unit to especially pay attention to this procedure.

Supporting this hypothesis, D1 receptor antagonists are already used in human trials for other purposes and the literature indicates that its collateral effects are dependent of chronic administration. Therefore, D1 receptor antagonist administration may be reasonably practical for treatment in humans.Furthermore, this treatment would not alter the perception of the traumatic event, but change the fear processing associated to it, by modulation of a specific dopaminergic mechanism.

\section{Financial support and sponsorship: Nil.}

Conflict of Interests: There are no conflicts of interest.

\section{REFERENCES}

Amos T, Stein DJ, Ipser JC. Pharmacological interventions for preventing post-traumatic stress disorder (PTSD). The Cochrane Library. 2014 Jan 1.

Astrup A, Greenway FL, Ling W, Pedicone L, Lachowicz J, Strader CD, Kwan R. Randomized controlled trials of the D1/D5 antagonist ecopipam for weight loss in obese subjects. Obesity. $2007 \mathrm{Jul}$ $1 ; 15(7): 1717-31$.

Bekinschtein P, Cammarota M, Igaz LM, Bevilaqua LR, Izquierdo I, Medina JH. Persistence of long-term memory storage requires a late protein synthesis-and BDNF-dependent phase in the hippocampus. Neuron. 2007 Jan 18;53(2):261-77.

Bethus I, Tse D, Morris RG. Dopamine and memory: modulation of the persistence of memory for novel hippocampal NMDA receptor-dependent paired associates. The Journal of Neuroscience. 2010 Feb 3;30(5):1610-8.

Breslau N, Kessler RC, Chilcoat HD, Schultz LR, Davis GC, Andreski P. Trauma and posttraumatic stress disorder in the community: the 1996 Detroit Area Survey of Trauma. Archives of general psychiatry. 1998 Jul 1;55(7):626-32.

Breslau N.The epidemiology of trauma, PTSD, and other posttrauma disorders.Trauma, Violence, \& Abuse.2009 Apr 30.

Bryant RA, Creamer M, O'Donnell M, Silove D, McFarlane AC. A study of the protective function of acute morphine administration on subsequent posttraumatic stress disorder. Biological psychiatry. 2009 Mar 1;65(5):438-40.

Chipkin RE, Iorio LC, Coffin VL, McQuade RD, Berger JG, Barnett A. Pharmacological profile of SCH39166: a dopamine D1 selective benzonaphthazepine with potential antipsychotic activity. Journal of Pharmacology and Experimental Therapeutics. 1988 Dec 1;247(3):1093-102.

Comings DE, Muhleman D, Gysin R. Dopamine D 2 receptor (DRD2) gene and susceptibility to posttraumatic stress disorder: A study and replication. Biological psychiatry. 1996 Sep 1;40(5):368-72.

Creamer M, Burgess P, McFarlane AC. Post-traumatic stress disorder: findings from the Australian National Survey of Mental Health and Well-being. Psychological medicine. 2001 Oct 1;31(07):1237-47.

Fletcher S, Creamer M, Forbes D. Preventing post traumatic stress disorder: are drugs the answer?.Australian and New Zealand Journal of Psychiatry. 2010 Dec 1;44(12):1064-71.

Frey U, Schroeder H. Dopaminergic antagonists prevent longterm maintenance of posttetanic LTP in the CA1 region of rat hippocampal slices. Brain research. 1990 Jul 2;522(1):69-75.

Gelpin E, Bonne O, Peri T, Brandes D, Shalev AY. Treatment of recent trauma survivors with benzodiazepines: a prospective study. The Journal of clinical psychiatry. 1996 Sep;57(9):390-4.

Heath FC, Jurkus R, Bast T, Pezze MA, Lee JL, Voigt JP, Stevenson CW. Dopamine D1-like receptor signalling in the hippocampus and amygdala modulates the acquisition of contextual fear conditioning. Psychopharmacology. 2015 Jul 1;232(14):2619-29.

Höflich A, Baldinger P, Savli M, Lanzenberger R, Kasper S. Imaging treatment effects in depression. Rev Neurosci. 2012: 23(3):22752 .

Holbrook TL, Galarneau MR, Dye JL, Quinn K, Dougherty AL. Morphine use after combat injury in Iraq and post-traumatic stress disorder.New England Journal of Medicine. 2010 Jan 14;362(2):110-7.

Huang YY, Kandel ER. Low-frequency stimulation induces a pathway-specific late phase of LTP in the amygdala that is mediated by PKA and dependent on protein synthesis. Learning \& Memory. 2007 Jul $1 ; 14(7): 497-503$.

Huang YY, Kandel ER. D1/D5 receptor agonists induce a protein synthesis-dependent late potentiation in the CA1 region of the hippocampus. Proceedings of the National Academy of Sciences. 1995 Mar 28;92(7):2446-50.

Izquierdo I, Furini CR, Myskiw JC. Fear memory. Physiological reviews. 2016 Apr 1;96(2):695-750.

Jay TM. Dopamine: a potential substrate for synaptic plasticity and memory mechanisms. Progress in neurobiology. $2003 \mathrm{Apr}$ 30;69(6):375-90.

Kahn I, Shohamy D. Intrinsic connectivity between the hippocampus, nucleus accumbens, and ventral tegmental area in humans.Hippocampus. 2013 Mar 1;23(3):187-92.

Kessler RC, Matthias A, Anthony JC, De Graaf R, Demyttenaere K, Gasquet I, De Girolamo G, Gluzman S, Gureje O, HARO J, Kawakami N. Lifetime prevalence and age-of-onset distributions of mental disorders in the World Health Organization's World Mental Health Survey Initiative.

Kessler RC, Sonnega A, Bromet E, Hughes M, Nelson CB. Posttraumatic stress disorder in the National Comorbidity Survey. Archives of general psychiatry 52.12 (1995): 1048-1060.

Kessler RC, Sonnega A, Bromet E, Hughes M, Nelson CB. Posttraumatic stress disorder in the National Comorbidity Survey. Archives of general psychiatry. 1995 Dec 1;52(12):1048-60.

Kontis D, Theochari E. Dopamine in anorexia nervosa: a systematic review. Behavioural pharmacology. 2012 Sep 1;23(5 and 6):496-515.

Lawford BR, Young R, Noble EP, Kann B, Ritchie T. The D 2 dopamine receptor (DRD2) gene is associated with co-morbid depression, anxiety and social dysfunction in untreated veterans with post-traumatic stress disorder. European Psychiatry. 2006 Apr 30;21(3):180-5.

Lemon N, Manahan-Vaughan D. Dopamine D1/D5 receptors gate the acquisition of novel information through hippocampal long-term potentiation and long-term depression. The Journal of neuroscience. 2006 Jul 19;26(29):7723-9.

Mellman TA, Byers PM, Augenstein JS. Pilot evaluation of hypnotic medication during acute traumatic stress response.Journal of traumatic stress. 1998 Jul 1;11(3):563-9. 
Miyake N, Miyamoto S, Jarskog LF. New serotonin/dopamine antagonists for the treatment of schizophrenia: are we making real progress?.Clinical schizophrenia \& related psychoses. 2012 Sep 24;6(3):122-33.

Muller JF, Mascagni F, McDonald AJ. Dopaminergic innervation of pyramidal cells in the rat basolateral amygdala.Brain Structure and Function. 2009 Feb 1;213(3):275-88.

O'Carroll CM, Martin SJ, Sandin J, Frenguelli B, Morris RG. Dopaminergic modulation of the persistence of one-trial hippocampusdependent memory.Learning \& Memory. 2006 Nov 1;13(6):760-9.

Parsons RG, Ressler KJ.Implications of memory modulation for post-traumatic stress and fear disorders.Nature neuroscience. $2013 \mathrm{Feb}$ 1;16(2):146-53.

Pillai A, Buckley PF. Reliable biomarkers and predictors of schizophrenia and its treatment. Psychiatric Clinics of North America. 2012 Sep 30;35(3):645-59.

Pitman RK, Delahanty DL. Conceptually driven pharmacologic approaches to acute trauma.CNS spectrums. 2005 Feb 1;10(02):99-106.

Pitman RK, Sanders KM, Zusman RM, Healy AR, Cheema F, Lasko NB, Cahill L, Orr SP. Pilot study of secondary prevention of posttraumatic stress disorder with propranolol. Biological psychiatry. 2002 Jan 15;51(2):189-92.

Rossato JI, Bevilaqua LR, Izquierdo I, Medina JH, Cammarota M. Dopamine controls persistence of long-term memory storage. Science. 2009 Aug 21;325(5943):1017-20.

Scatton B, Simon H, Le Moal M, Bischoff S. Origin of dopaminergic innervation of the rat hippocampal formation. Neuroscience letters. 1980 Jun 1;18(2):125-31.

Schelling G, Kilger E, Roozendaal B, Dominique JF, Briegel J, Dagge A, Rothenhäusler HB, Krauseneck T, Nollert G, Kapfhammer HP. Stress doses of hydrocortisone, traumatic memories, and symptoms of posttraumatic stress disorder in patients after cardiac surgery: a randomized study. Biological Psychiatry. 2004 Mar 15;55(6):627-33.

Schelling G, Briegel J, Roozendaal B, Stoll C, Rothenhäusler HB, Kapfhammer HP. The effect of stress doses of hydrocortisone during septic shock on posttraumatic stress disorder in survivors. Biological psychiatry. 2001 Dec 15;50(12):978-85.

Seeman P. Dopamine D2 receptors as treatment targets in schizophrenia.Clinical schizophrenia \& related psychoses. 2010 Mar 24:4(1):56-73.
Segman RH, Cooper-Kazaz R, Macciardi F, Goltser T, Halfon Y, Dobroborski T, Shalev AY. Association between the dopamine transporter gene and posttraumatic stress disorder.Molecular psychiatry. 2002 Sep;7(8):903-7.

Shin LM, Handwerger K. Is posttraumatic stress disorder a stress-induced fear circuitry disorder?.Journal of traumatic stress. 2009 Oct 1;22(5):409-15.

Stein MB, Kerridge C, Dimsdale JE, Hoyt DB. Pharmacotherapy to prevent PTSD: Results from a randomized controlled proof-of-concept trial in physically injured patients. Journal of traumatic stress. 2007 Dec 1;20(6):923-32.

Suliman S, Seedat S, Pingo J, Sutherland T, Zohar J, Stein DJ. Escitalopram in the prevention of posttraumatic stress disorder: a pilot randomized controlled trial. BMC psychiatry. 2015 Feb 19;15(1):1.

Swanson LW. The projections of the ventral tegmental area and adjacent regions: a combined fluorescent retrograde tracer and immunofluorescence study in the rat. Brain research bulletin. $1982 \mathrm{Dec}$ 31;9(1):321-53.

Taber KH, Black DN, Porrino LJ, Hurley RA. Neuroanatomy of dopamine: reward and addiction. The Journal of neuropsychiatry and clinical neurosciences. 2012 Jan;24(1):1-4.

Vaiva G, Ducrocq F, Jezequel K, Averland B, Lestavel P, Brunet A, Marmar CR. Immediate treatment with propranolol decreases posttraumatic stress disorder two months after trauma. Biological psychiatry. 2003 Nov 1;54(9):947-9.

Zhang J, Xiong B, Zhen X, Zhang A. Dopamine D1 receptor ligands: where are we now and where are we going. Medicinal research reviews. 2009 Mar 1;29(2):272-94.

\section{How to cite this article:}

Moulin TC. Dopaminergic Receptor Type 1 Antagonists and its Possible Role as Preventive Treatment of Post-Traumatic Stress Disorder: A Short Review. J App Pharm Sci, 2016; 6 (12): 239242. 